\title{
Pembekalan Pemahaman Metode Pembuktian Matematika dan Penerapan Strategi Abduktif-Deduktif Untuk Mengembangkan Kemampuan Membuktikan Konsep Aljabar Abstrak Pada Mahasiswa Jurusan Matematika FMIPA UNJ
}

\author{
Ellis Salsabila ${ }^{1}$, Ratnaningsih ${ }^{2}$, Ibnu Hadi ${ }^{3}$ \\ 1,2) Jurusan Matematika, Fakultas MIPA, Universitas Negeri Jakarta \\ Jl. Rawamangun Muka Jakarta Timur 13220 \\ Email: ellissalsabila@yahoo.com, r4tn404@yahoo.com \\ 3) Jurusan Matematika, Fakultas MIPA, Universitas Negeri Jakarta \\ Jl. Rawamangun Muka Jakarta Timur 13220 \\ Email: ibnu_unj@yahoo.co.id
}

\begin{abstract}
ABSTRAK
Penelitian ini bertujuan untuk memperoleh informasi tentang strategi pembelajaran yang efektif dalam mengembangkan kemampuan mahasiswa akan pembuktian konsep-konsep matematika didalam perkuliahan Aljabar Abstrak. Metode yang digunakan dalam penelitian ini adalah quasi eksperiment dengan desain penelitian posttest-only kontrol group design. Populasi penelitian adalah seluruh mahasiswa Jurusan Matematika FMIPA UNJ pada tahun akademik 2013/2014 sementara sampel penelitian diambil dengan teknik multistage random sampling terpilih kelas eksperimen adalah mahasiswa program studi Pendidikan Matematika Reguler Angkatan Tahun 2012/2013, sementara untuk kelas kontrol adalah mahasiswa program studi Pendidikan Matematika Non Reguler Angkatan Tahun 2012/2013. Variabel terikat dalam penelitian ini adalah kemampuan membuktikan konsep matematika mahasiswa pada mata kuliah Aljabar Abstrak dan variable bebas adalah strategi pembelajaran yang terdiri dari strategi abduktif deduktif dan pembelajaran konvensional yang disertai dengan pembekalan pemahaman metode-metode pembuktian matematika. Berdasarkan data hasil post test kemampuan membuktikan konsep Aljabar Abstrak yang dianalisis dengan menggunakan Independent Samples T Test melalui software SPSS 17 diperoleh nilai $t=3,214$ dengan $\mathrm{db}=55$ dan $\mathrm{p}$ value $=0,001<0,05$, dengan demikian hipotesis penelitian yang diajukan teruji oleh data, sehingga disimpulkan bahwa rata-rata kemampuan membuktikan konsep-konsep Aljabar Abstrak mahasiswa yang diberikan pemahaman metode pembuktian matematika secara eksplisit di awal perkuliahan bersamaan dengan penerapan strategi Abduktif-Deduktif lebih tinggi dari pada mahasiswa yang memperoleh pembelajaran secara konvensional.
\end{abstract}

Kata kunci: Strategi abduktif-deduktif, Kemampuan membuktikan matematika.

\section{ABSTRACT}

This aims of this study is to obtain information about effective learning strategies in developing students'ability to prove mathematical concepts in Abstract Algebra course. The used method in this study was quasi experiment with posttest-only kontrol group design. Research population of this study was students of the Department of Mathematics of Jakarta State University (UNJ) in the academic year 2013/2014. The selected samples are students of Mathematics Education Regular year 2012/2013, taken with multistage random sampling technique. While the kontrol samples were students of Mathematics Education Non-Regular year 2012/2013.The dependent variable in this study is the students'ability to prove the concept of mathematics in Abstract Algebra course, and the independent variable is the learning strategy that consists of abductive-deductive strategy and conventional learning accompanied by debriefing the understanding of mathematical proof methods. The data of Post test result were being analyzed by Independent Samples T Test through SPSS 17 software, obtaining the $t$-value $=3.214$ with $d b=55$ and $p$-value $=0.001<0.05$. This value showed that the proposed hypothesis is tested by the data . We can conclude that the students'average ability to prove the concepts of Abstract Algebra are higher to those who were given the understanding of mathematical proof method explicitly at the beginning of the course along side with the application of abductive-deductive strategy compared to the students who receive conventional learning.

Keywords: Abductive-deductive strategy, the ability to prove mathematical concept. 


\section{Pendahuluan}

\subsection{Latar Belakang Masalah}

Matakuliah Aljabar Abstrak merupakan salah satu matakuliah dalam kurikulum Jurusan/Program Studi Matematika dan Pendidikan Matematika di semua Perguruan Tinggi di Indonesia. Isi mata kuliah aljabar abstrak berdasarkan kurikulum pendidikan matematika dan ilmu pengetahuan alam, untuk program S1 LPTK adalah: (1) Tinjauan ulang tentang operasi dan himpunan, pemetaan dan relasi ekivalen, (2) Grup meliputi: sifat-sifat dan contoh grup, order grup, sifat-sifat dan contoh grup siklis, sifat-sifat dan contoh subgrup, subgroup normal, homomorfisma grup, peta dan kernel, (3) Ring meliputi: sifat-sifat dan contoh ring, sifat-sifat dan contoh subring, homomofisma ring, daerah integral, field dan ideal, dan (4) Ring polinom atas field bilangan real.

Sebagai mata kuliah Aljabar Abstrak memberikan dasar untuk melakukan proses analisis dan pengkajian yang lebih mendalam dan terstruktur tentang konsep-konsepnya. Pendekatan yang digunakan dalam mempelajari Aljabar Abstrak lebih di dominasi pada kegiatan menalar, mengkaji, menganalisis, dan membuktikan yang merupakan kemampuan kognitif tingkat tinggi.

Sementara pada tahun-tahun pertama mahasiswa Program Studi Matematika dan Pendidikan Matematika terbiasa, terlatih dan terampil dengan kegiatan belajar yang merupakan kegiatan menghitung, mencari, men-drill atau membuktikan konsep-konsep matematika yang sederhana sehingga pada saat mereka menerima mata kuliah Aljabar Abstrak ataupun Analisis Real yang mempunyai pendekatan berbeda dengan yang sudah mereka alami sebelumnya, mereka pun banyak yang mendapatkan kesulitan.

Kesulitan umumnya ditemukan pada masalah pembuktian konsep baik dalam hal memahami bukti dari teorema, lemma, corollary, ataupun dalam hal menyelesaikan soal-soal pembuktian. penyebab kesulitan tersebut, antaranya adalah (1) kurangnya pemahaman mahasiswa terhadap konsep yang akan dibuktikan, mereka masih mengalami kesulitan dalam mengidentifikasi apa yang diketahui, apa yang akan dibuktikan, (2) kurangnya pemahaman tentang metode-metode pembuktian yang akan digunakan, (3) kurangnya kemampuan dalam menggunakan/memanipulasi fakta-fakta yang diketahui dan mengkaitkannya dengan yang akan ditunjukkan serta (4) kurangnya kemampuan dalam menyusun alur/sistematika bukti tersebut.

Menurut Moore (1994) telah melakukan identifikasi terhadap kelemahan dan kesulitan mahasiswa dalam pembuktian matematika, yang dikelompokkan ke dalam tujuh jenis kesulitan, sebagai berikut:

1. Mahasiswa tidak dapat menyatakan definisi dengan bahasanya sendiri.

2. Intuisi pemahaman terhadap suatu konsep yang dimiliki mahasiswa sedikit.

3. Gambaran konsep (concept images) untuk mengerjakan pembuktian tidak cukup.

4. Mahasiswa tidak dapat dan tidak berkeinginan membuat contoh sendiri

5. Mahasiswa tidak mengetahui bagaimana menggunakan definisi untuk memperoleh struktur pembuktian yang menyeluruh.

6. Mahasiswa tidak dapat memahami dan menggunakan bahasa dan notasi matematik.

7. Mahasiswa tidak mengetahui bagaimana memulai pembuktian

Menurut Arnawa (2006) dari sisi mahasiswa, kesulitan Aljabar Abstrak misalnya disebabkan oleh: (1) konsep-konsep dalam Aljabar Abstrak sangat abstrak, (2) banyak contoh-contoh yang berkenaan dengan konsep, tidak dikenali dengan baik oleh mahasiswa, (3) banyak mahasiswa yang belum terbiasa dengan pembuktian deduktif. Hal seperti ini ternyata tidak hanya terjadi di Indonesia, tetapi juga di negaranegara maju seperti yang dinyatakan oleh Leron \& Dubinsky (1995) dan Lajoie (Carlson, 2003). Semua ini berujung pada rendahnya kualitas pemahaman mahasiswa dalam aljabar abstrak.

Padahal bukti/pembuktian memainkan peranan penting dalam Aljabar Abstrak (Findel, 2001), banyak manfaat yang dapat diperoleh dari pengalaman membuktikan ini, salah satunya adalah melatih logically thinking dalam belajar matematika. Bukti/pembuktian merupakan karakteristik utama dari kegiatan bermatematika dan menjadi komponen kunci dalam pembelajaran matematika (Arnawa, 2006). Di Amerika Serikat, National Council of Teacher of Mathematics (2000) telah menetapkan agar bukti/pembuktian dimasukkan dalam kurikulum matematika. Di Indonesia, siswa juga dikehendaki agar mempunyai kemampuan dalam membuat bukti/pembuktian. Schoenfeld (Hanna \& Jahnke, 1996) dalam Arnawa (2006) menyatakan bahwa masih sedikit sekali siswa yang menyadari pentingnya suatu 
pembuktian. Penelitian yang berkenaan dengan pembuktian matematika di perguruan tinggi, khususnya pembuktian dalam teori grup (aljabar abstrak), misalnya telah dilakukan oleh Hart (1994), Moore (Findell, 2001), dan Asikin (2002). Mereka menyimpulkan bahwa sebagian besar mahasiswa masih kesulitan dalam membuat pembuktian.

Menurut Reid (Sabri, 2004), Bukti/pembuktian membuat matematika unik dan berbeda dari disiplin ilmu lainnya. Melalui tugas pembuktian, dosen dapat melihat: (1) bagaimana kemampuan mahasiswa dalam beragumentasi secara logis, (2) bagaimana mahasiswa menggunakan contoh dan lawan contoh untuk mendukung argumentasinya, (3) kelemahan-kelemahan apa saja yang dialami mahasiswa dalam bernalar, dan (4) miskonsepsi apa yang sering dialami mahasiswa. Sementara Epp (Sabri, 2003) menyatakan bahwa salah satu pendekatan yang paling baik untuk mengembangkan kemampuan berpikir abstrak siswa/mahasiswa adalah melalui keterlibatan yang bermakna dalam mengkonstruksi dan menyelesaikan pembuktian-pembuktian matematika.

Untuk dapat menyelesaikan masalah pembuktian, diperlukan pula pemahaman tentang teknik-teknik pembuktian, namun kenyataannya belum semua mahasiswa memahami dengan baik teknik-teknik pembuktian matematika, seperti pembuktian langsung, pembuktian tidak langsung, pembuktian dua arah, prinsip induksi matematika dan sebagainya. Teknik-teknik pembuktian hanya terdapat secara implicit dalam beberapa mata kuliah seperti Kalkulus, PDM, ataupun Teori Bilangan, dan tidak pernah dipelajari secara tersendiri tentang teknik-teknik pembuktian matematika dengan lengkap yang meliputi pengertian, struktur, prosedur dan contoh penerapannya Oleh karena itu dalam perkuliahan aljabar abstrak ini pembekalan akan pemahaman teknik-teknik pembuktian matematika dirasakan perlu untuk disampaikan tersendiri secara eksplisit diawal perkuliahan dalam 1 (satu) atau 2 (dua) kali pertemuan.

Disamping pembekalan akan pemahaman teknik-teknik pembuktian matematika, perlu juga diupayakan penerapan strategi-strategi pembelajaran yang dapat mengatasi kesulitan-kesulitan mahasiswa dan dapat menjembatani peningkatan tahap berpikir mahasiswa agar kemampuan membuktikan mahasiswa, dapat berkembang secara optimal. Beberapa pendekatan/strategi pembelajaran yang mengembangkan kemampuan pembuktian matematika untuk tingkat mahasiswa ini telah diteliti oleh peneliti sebelumnya diantaranya : Uhlig (2003) yang mengembangkan suatu pendekatan untuk memahami dan mengkonstruksi suatu pembuktian pada mata kuliah Aljabar Linear elementer dengan pendekatan WWHWT (What, Why, How, What and Theorems), Arnawa (2006) yang menggunakan strategi pembelajaran berdasarkan teori APOS (Action, Process, Object and Schema) pada mata kuliah Aljabar Abstrak, Kusnandi (2008) yang menggunakan pembelajaran dengan strategi Abduktif-Deduktif (PSAD) pada mata kuliah Teori Bilangan dan Yerison (2011) yang menggunakan strategi pembelajaran berdasarkan teori M-APOS (APOS yang dimodifikasi) pada mata kuliah Analisis Real.

Pada penelitian ini untuk mengatasi kesulitan mahasiswa dalam memahami materi Aljabar Abstrak khususnya dalam hal pembuktian matematika maka akan digunakan pendekatan pembelajaran melalui penerapan strategi Abduktif-Deduktif. Pendekatan Pembelajaran melalui penerapan strategi Abduktif-Deduktif telah diteliti oleh Kusnandi yang berhasil dalam menumbuhkembangkan kemampuan membuktikan pada mahasiswa dalam perkuliahan Teori Bilangan. Pembelajaran dengan strategi Abduktif Deduktif adalah pembelajaran dengan strategi pemecahan masalah yang dalam proses penyelesaian masalah tersebut mahasiswa diberikan tuntunan untuk mengarahkan cara berpikirnya yang menggabungkan berpikir secara deduktif dan abduktif. Karakteristik utama dari pembelajaran dengan strategi Abduktif-Deduktif ini adalah strategi pemecahan masalah yang bertumpu pada penentuan target perantara yang dapat menjembatani antara target akhir yang harus dicapai atau diperoleh dari penyelesaian masalah dengan informasi atau fakta yang diberikan atau dimiliki.

Pembelajaran dengan strategi Abduktif-Deduktif ini merupakan strategi pembelajaran yang dimulai dengan menyajikan masalah kepada mahasiswa, kemudian mahasiswa dituntut untuk dapat mengelaborasi setiap informasi atau fakta yang diberikan dalam masalah tersebut secara deduktif, serta merumuskan suatu kondisi secara abduktif agar target akhir yang diharapkan dapat tercapai. Masalah yang diberikan harus dapat mengantarkan mahasiswa untuk memahami objek-objek matematika dan kaitan antara objek matematika yang satu dengan objek yang lainnya, sementara dosen berperan 
sebagai motivator yang mendorong mahasiswa untuk melakukan diskusi transaktif, yaitu diskusi yang mendorong mahasiswa untuk melakukan transactive reasoning seperti mengkritik, menjelaskan, mengklarifikasi, menjastifikasi dan mengelaborasi suatu gagasan yang diajukan, baik yang diinisiasi oleh mahasiswa maupun dosen.

Oleh karena itu perlu diteliti tentang penerapan strategi Abduktif-Deduktif untuk mengembangkan kemampuan membuktikan mahasiswa didalam pembelajaran Aljabar Abstrak yang disertai dengan pembekalan akan pemahaman teknik-teknik pembuktian matematika di awal-awal perkuliahan.

\subsection{Rumusan Masalah}

Rumusan masalah dalam penelitian ini adalah : Apakah tingkat kemampuan membuktikan konsepkonsep Aljabar Abstrak mahasiswa yang diberikan pemahaman teknik-teknik pembuktian matematika secara eksplisit di awal perkuliahan bersamaan dengan penerapan strategi Abduktif-Deduktif akan lebih tinggi dari pada mahasiswa yang memperoleh pembelajaran secara konvensional?

\subsection{Tujuan Penelitian}

Untuk memperoleh informasi tentang strategi pembelajaran yang efektif dalam mengembangkan kemampuan mahasiswa akan pembuktian konsep-konsep matematika didalam perkuliahan Aljabar Abstrak.

\section{Metode Penelitian}

\subsection{Jenis dan Metode Penelitian}

Jenis penelitian yang dilakukan adalah penelitian kuantitatif dengan metode quasi eksperiment.

\subsection{Tempat dan Waktu Penelitian}

Penelitian ini dilaksanakan pada Jurusan Matematika FMIPA UNJ. Waktu pelaksanaan penelitian pada semester genap tahun akademik 2013/ 2014, pelaksanaan penelitian lapangan atau treatment/perlakuan dikelas dilaksanakan selama 2 bulan yaitu pada bulan Mei - Juni 2014. Sementara analisis data dan penyusunan laporan penelitian dilaksanakan pada bulan Juli - Oktober 2014.

\subsection{Desain Penelitian}

Dalam penelitian ini digunakan desain penelitian posttest-only kontrol group design dengan desain sebagai berikut:

\begin{tabular}{|l|l|l|}
\hline $\mathrm{E}$ & $\mathrm{T}_{1}$ & $\mathrm{X}_{1}$ \\
\hline $\mathrm{O}$ & $\mathrm{T}_{2}$ & $\mathrm{X}_{2}$ \\
\hline
\end{tabular}

Keterangan :

E : Kelas Eksperimen $\quad$ T1: Perlakuan Kelas Eksperimen

$\mathrm{O}:$ Kelas Kontrol ketiga

\subsection{Rancangan Perlakuan}

Rancangan perlakuan dalam penelitian ini mengikuti posttest-only kontrol group design seperti yang digambarkan di atas, dimana pada kelas eksperimen diberikan perlakuan pembelajaran Aljabar Abstrak dengan menggunakan strategi Abduktif-Deduktif yang disertai dengan memberikan pemahaman metode pembuktian matematika secara eksplisit di awal perkuliahan. Dalam menunjukkan proses pembuktian konsep Aljabar Abstrak dosen menggunakan logika AbduktifDeduktif.

Sementara pada kelas kontrol diberikan pembelajaran secara konvensional yaitu pembelajaran dengan menggunakan metode ceramah, diskusi, tanya jawab, dan penugasan. Dimana dalam menunjukkan proses pembuktian konsep Aljabar Abstrak dosen menggunakan logika deduktif, dan pemahaman tentang metode pembuktian matematika dilakukan secara implisit didalam Pembelajaran.

\subsection{Populasi dan Sampel Penelitian}


Populasi target dalam penelitian ini adalah seluruh mahasiswa Jurusan Matematika FMIPA UNJ pada tahun akademik 2013/2014, sementara pupulasi terjangkau adalah seluruh mahasiswa Jurusan Matematika FMIPA UNJ pada tahun akademik 2013/2014 yang mengambil mata kuliah Aljabar Abstrak. Sampel penelitian diambil dengan teknik multistage random sampling dimana pada tahap pertama digunakan teknik purposive sampling yaitu memilih sampel berdasarkan pertimbangan tertentu. Maka dipilih dua kelas mahasiswa pada populasi terjangkau yang keduanya berasal dari Program Studi Pendidikan Matematika dengan pertimbangan memiliki sebaran kurikulum yang sama dan diampu oleh dosen yang sama. Kemudian pada tahap kedua memilih secara acak satu kelas sebagai kelas eksperimen dan kelas lainnya sebagai kelas kontrol. Maka terpilih kelas eksperimen dan kelas kontrol adalah mahasiswa program studi Pendidikan Matematika Reguler dan Non Reguler Angkatan Tahun 2012/2013.

\subsection{Kontrol Validitas Internal dan Eksternal}

Agar eksperimen yang dilakukan memenuhi syarat validitas internal dan eksternal suatu eksperimen maka sebelum eksperimen dilakukan, terlebih dahulu dilakukan pengontrolan terhadap variabel sekunder yang dapat mempengaruhi validitas penelitian eksperimen tersebut. Pengontrolan tersebut meliputi :

1. Sampel ditetapkan dari populasi berdasarkan teknik pengambilan sampel yang memenuhi kriteria pensampelan.

2. Perlakuan/treatment dilakukan pada subyek yang sama/homogen dari aspek usia/kematangan yaitu mahasiswa-mahasiswa yang berasal dari angkatan tahun yang sama, yang memiliki kelahiran sekitar tahun 1994 atau mereka berusia sekitar 20 tahun, sehingga tingkat kematangan kedua kelas sampel adalah sama/homogen.

3. Perlakuan/treatment dilakukan pada subyek yang sama/homogen dari aspek intelegensi yaitu yang memiliki kemampuan akademik rata-rata sama.

4. Perlakuan/treatment dilaksanakan dalam waktu yang tidak terlalu lama yaitu selama 6 kali tatap muka dengan waktu sekitar 6 minggu.

5. Menetapkan dosen pengajar Aljabar Abstrak yang sama untuk mengajar dikedua kelas eksperimen dan kontrol.

6. Mengontrol obyektifitas perlakuan dengan melaksanakan perlakuan/treatment sewajar mungkin dan apa adanya, serta menjaga agar mahasiswa tidak mengetahui bahwa sedang dilakukan penelitian pada kuliah yang sedang diikutinya.

\subsection{Teknik Pengumpulan Data}

Data dalam penelitian ini berupa hasil posttest kemampuan membuktikan konsep aljabar abstrak yang diperoleh dari mahasiswa di kedua kelas sampel pada mata kuliah Aljabar Abstrak.

1. Definisi Konseptual Kemampuan Membuktikan Konsep Aljabar Abstrak

Berdasarkan beberapa definisi kemampuan membuktikan yang telah diteliti sebelumnya dalam Arnawa (2006) dan Kusnandi (2008) maka kemampuan membuktikan konsep aljabar abstrak yang dimaksud dalam penelitian ini adalah kemampuan membaca bukti dan mengkonstruksi/menyusun bukti dari suatu konsep aljabar abstrak, dimana dalam kemampuan pembuktian tersebut mencakup kemampuan menggunakan metode-metode pembuktian matematika (bukti langsung, bukti tidak langsung dll), kemampuan mengorganisir dan memanipulasi argumen-argumen (fakta/premis, definisi, lemma atau teorema/dalil) dan kemampuan merangkai langkah-langkah yang logis.

Aspek atau indikator kemampuan membuktian konsep Aljabar Abstrak yang diukur secara lebih rinci meliputi : (1) kemampuan membaca bukti, yaitu kemampuan mengidentifikasi apa yang diketahui (fakta/premis) dan apa yang harus ditunjukkan (konklusi), (2) kemampuan menggunakan metode-metode pembuktian (bukti langsung, bukti tidak langsung dll), (3) kemampuan mengorganisasikan dan memanipulasi fakta-fakta yang diketahui atau yang telah terbukti kebenarannya (definisi, lemma dan teorema), (4) kemampuan membuat koneksi antara fakta yang diberikan/diketahui dengan unsur-unsur dari konklusi yang hendak dibuktikan, (5) kemampuan menyusun/menuliskan bukti menurut alur/ sitematika yang hierarkis, logis dan sistematis, serta (6) kemampuan dalam melengkapi alasan dari setiap langkah yang diambil atau dipilih. 


\section{Definisi Operasional Kemampuan Membuktikan Konsep Aljabar Abstrak}

Dari definisi konseptual diatas diturunkan definisi operasional bahwa yang dimaksud kemudian dengan kemampuan membuktikan konsep Aljabar Abstrak adalah skor hasil tes mahasiswa pada tes kemampuan pembuktian matematika pada konsep-konsep Aljabar Abstrak dengan pokok bahasan Ring yang mencakup sub pokok bahasan : Ring, Integral Domain, Field, Ideal dan Homomorfisma Ring.

\section{Instrumen}

Instrumen yang digunakan untuk memperoleh data adalah instrumen test berbentuk essay yang terdiri dari 6 butir soal dan dikerjakan dalam waktu 120 menit dengan skor maksimum 72 yang kemudian dikonversi menjadi 100. Instrumen test disusun mencakup aspek konsep Ring dan aspek kemampuan pembuktian matematika.

\section{Pengujian Validitas dan Perhitungan Reliabilitas}

Sebelum instrumen tes digunakan untuk memperoleh data, maka diuji terlebih dahulu validitas dan reabilitasnya. Uji validitas yang dilakukan adalah uji validitas konsep yaitu dengan memeriksa kesesuaian butir soal/item baik terhadap indikator konsep Aljabar Abstrak yang diukur, maupun terhadap indikator dari kemampuan pembuktian matematika seperti yang telah dijabarkan diatas, uji ini melalui penelaahan kisi-kisi test untuk memastikan bahwa butir soal test sudah mewakili keseluruhan konsep (isi dan konstruk) yang harus dikuasai dan diukur. Uji validitas konsep dilakukan oleh panel yang terdiri dari 3 orang dosen pengajar Aljabar Abstrak, dari hasil uji validitas konsep tersebut diperoleh bahwa instrument test valid untuk mengukur indikator konsep Aljabar Abstrak maupun indikator kemampuan pembuktian matematika. Untuk reliabilitas instrumen tes diuji dengan menggunakan rumus koefisien korelasi Alpha Cronbach.

Melalui bantuan software SPSS 17, diperoleh koefisien reliabilitas Alpha Cronbach rii $=0,63$ (lampiran 3 hal 61) . Koefisien reliabilitas ini kecil, hal ini menunjukkan reliabilitas instrument test kurang begitu baik. Namun karena waktu yang tidak cukup tersedia untuk memperbaiki instrument test dan melakukan uji coba instrument test hasil revisi maka instrument test tetap digunakan terhadap responden penelitian.

\subsection{Analisis Data}

\section{Sebelum Perlakuan}

Agar eksperimen yang dilakukan memenuhi syarat validitas internal dan eksternal suatu eksperimen dalam hal kemampuan awal akademik kedua kelas sampel adalah memiliki rata-rata yang sama, maka dilakukan analisis deskripsi terhadap data skor UTS Aljabar Abstrak yang mereka peroleh sebelum perlakuan dilaksanakan.

\section{Setelah Perlakuan}

Untuk analisa data dalam hal uji rata-rata satu pihak akan digunakan uji-t, sebelum analisis data dilakukan uji persyaratan analisis yang meliputi uji normalitas dengan menggunakan uji Kolmogorov Smirnov dan uji Shapiro Wilk, sementara uji homogenitas diantara kedua kelas dengan menggunakan Levene's Test melalui bantuan software SPSS 17. Untuk uji hipotesis penelitian digunakan Uji-t (Independent Samples T Test) yang sesuai dengan asumsi untuk kesamaan variance (berdasarkan hasil uji homogenitas) juga melalui bantuan software SPSS 17.

\subsection{Hipotesis Statistik}

$\mathrm{H}_{0}$ : (Rata-rata kemampuan membuktikan pada mahasiswa kelas eksperimen lebih rendah atau sama dengan rata-rata kemampuan membuktikan mahasiswa kelas kontrol)

$\mathrm{H}_{1}$ : (Rata-rata kemampuan membuktikan pada mahasiswa kelas eksperimen lebih tinggi daripada rata-rata kemampuan membuktikan mahasiswa kelas kontrol).

\section{Hasil dan Pembahasan}

\subsection{Deskripsi Data}

Data dalam penelitian ini merupakan data posttest kemampuan membuktikan konsep Aljabar Abstrak yang diambil setelah perlakuan selama 7 pertemuan/tatap muka dari minggu ke sembilan hingga ke lima belas pada pokok bahasan Ring dan Field di kedua kelas ekperimen dan kontrol. Kelas ekperimen terdiri dari 30 mahasiswa yang diberikan pemahaman metode pembuktian matematika secara eksplisit 
di awal perkuliahan bersamaan dengan penerapan strategi Abduktif-Deduktif. Sedangkan kelas kontrol terdiri dari 27 mahasiswa yang yang memperoleh pembelajaran secara konvensional. Tabel berikut menyajikan statistik deskriptif dari data hasil posttest kemampuan membuktikan konsep Aljabar Abstrak dari kedua kelas eksperimen dan kontrol.

Tabel 1. Statistik deskriptif kedua kelas sampel

\begin{tabular}{|l|l|l|}
\hline Statistik & Kelas Eksperimen & Kelas Kontrol \\
\hline N (jumlah siswa) & 30 & 27 \\
\hline Nilai minimum & 45 & 35 \\
\hline Nilai maksimum & 80 & 70 \\
\hline Rentang (Jangkauan) & 35 & 35 \\
\hline Rata-rata & 58,77 & 50,59 \\
\hline Varians (s') & 70.737 & 115.481 \\
\hline Simpangan baku (s) & 8.411 & 10.746 \\
\hline Kuartil I (Q1) & 52 & 42 \\
\hline Median & 57 & 50 \\
\hline Kuartil III (Q3) & 64 & 58 \\
\hline Interquartile Range & 12 & 16 \\
\hline Kemencengan (Skewness) & 0,633 & 0,445 \\
\hline & &
\end{tabular}

Pada tabel 1 di atas, diketahui bahwa rata-rata hasil posttest kemampuan membuktikan konsep Aljabar Abstrak dari kedua kelas eksperimen dan kontrol berturut-turut adalah 58,77 dan 50,59. Hal ini menunjukkan bahwa rata-rata kemampuan membuktikan pada kelas eksperimen lebih tinggi daripada kelas kontrol. Sementara itu, berdasarkan hasil perhitungan simpangan baku kedua kelas, terlihat bahwa simpangan baku pada kelas eksperimen lebih kecil daripada simpangan baku pada kelas kontrol. hal ini berarti mahasiswa pada kelas eksperimen lebih seragam daripada mahasiswa kelas kontrol. Untuk lebih jelasnya, data hasil posttest kemampuan membuktikan konsep Aljabar Abstrak dari kedua kelas eksperimen dan kontrol disajikan dalam diagram kotak-garis berikut yang diperoleh dengan menggunakan bantuan software SPSS 17.

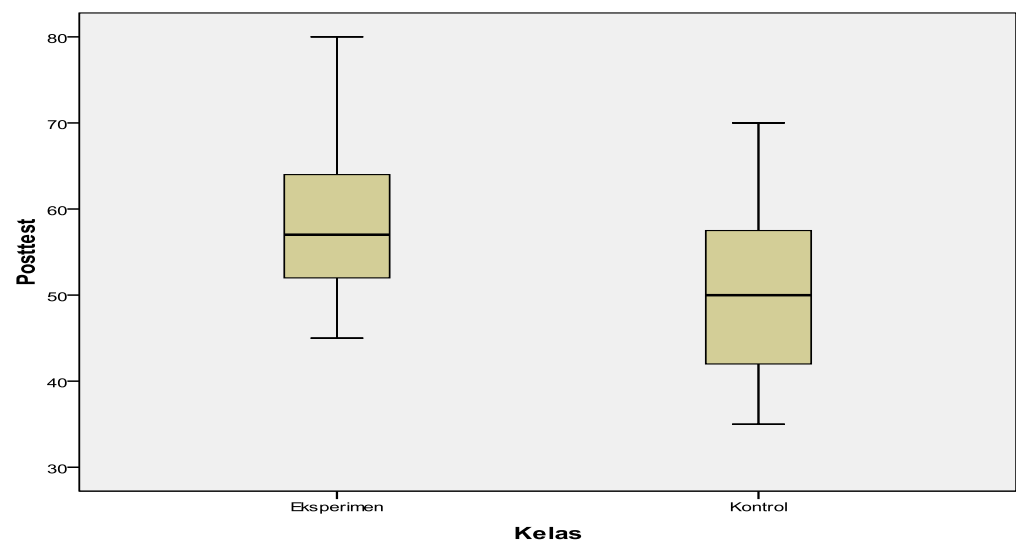

Gambar 1. Diagram Kotak-Garis Data Kemampuan Pembuktian

Pada diagram kotak-garis di atas, Q1 ditunjukkan oleh garis horizontal bagian bawah pada persegi panjang, Q2 ditunjukkan oleh garis horizontal pada bagian dalam persegi panjang, dan Q3 ditunjukkan oleh garis horizontal bagian atas pada persegi panjang. Pada kelas eksperimen memperlihatkan bahwa nilai Q2 lebih dekat dengan nilai Q1, maka dapat dikatakan bahwa data lebih terpusat di bawah median dan lebih menyebar di atas median. Sedangkan pada kelas kontrol terlihat bahwa median terletak di tengah kotak diagram kotak-garis, maka dapat dikatakan data menyebar dibawah dan diatas median. Sementara itu pada diagram kotak-garis kedua kelas eksperimen dan kontrol terlihat bahwa panjang kedua ekornya tidak sama, di mana ekor (whisker) bagian atas lebih panjang daripada ekor bagian bawah diagram kotak-garis. Hal ini menunjukkan bahwa distribusi data kelas ekperimen dan kelas kontrol tidak simetris, yaitu cenderung menjulur ke kanan (positive skewness). 


\subsection{Pengujian Prasyarat Analisis Data}

\section{Uji Prasyarat Sebelum Perlakuan}

Agar eksperimen yang dilakukan memenuhi syarat validitas internal dan eksternal suatu eksperimen dalam hal kemampuan awal akademik kedua kelas sampel adalah memiliki rata-rata yang sama, maka dilakukan analisis deskripsi terhadap data skor UTS Aljabar Abstrak yang mereka peroleh sebelum perlakuan dilaksanakan. Hal ini untuk menjaga agar perbedaan yang terjadi pada variabel terikat di akhir perlakuan adalah karena diakibatkan perlakuan yang dilaksanakan, bukan karena faktor yang lain, seperti kemampuan awal yang sudah berbeda.

Melalui analisis deskripsi yang dilakukan terhadap data skor UTS Aljabar Abstrak sebelum perlakuan, diperoleh bahwa dari segi kemampuan awal akademik kedua kelas sampel memiliki kemampuan ratarata sama, hal ini terlihat dari nilai rata-rata skor UTS kedua kelas sampel yang diperoleh berkisar diantara 81-82, yaitu rata-rata skor UTS kelas eksperimen 81,2 dan kelas kontrol 82,56. Dengan demikian syarat sebelum perlakuan bahwa kemampuan rata-rata akademik kedua kelas sampel adalah sama/homogen dipenuhi.

\section{Uji Prasyarat Analisis Data}

(a) Uji Normalitas

Uji normalitas atas data kelas eksperimen dan kelas kontrol dilakukan dengan uji Kolmogorov Smirnov dan uji Shapiro Wilk melalui software SPSS 17. Dengan hipotesis uji normalitas sebagai berikut:

$\mathrm{H}_{\mathrm{o}}$ : Data berdistribusi normal

$\mathrm{H}_{1}$ : Data tidak berdistribusi normal

Kriteria Uji : Terima Ho jika Sig >0,05

Dari tabel hasil output Test of Normality kedua kelas eksperimen dan kontrol diperoleh bahwa nilai Sig $>0.05$, dimana dengan uji Kolmogorov-Smirnov pada kelas eksperimen sig $=0,2$ dan pada kelas kontrol sig $=0,165$, sementara dengan uji Shapiro-Wilk pada kelas eksperimen sig $=0,365$ dan pada kelas kontrol sig $=0,066$ semuanya menunjukkan nilai Sig $>0.05$, sehingga Ho diterima, artinya baik data kelas eksperimen maupun kelas kontrol keduanya berdistribusi normal. .

\section{(b) Uji Homogenitas}

Uji homogenitas kedua data kelas eksperimen dan kelas kontrol dilakukan dengan Levene's Test melalui software SPSS 17. Dengan hipotesis uji homogenitas sebagai berikut:

Ho : $\sigma_{1}^{2}=\sigma_{2}^{2}$

$H_{1}: \sigma_{1}^{2} \neq \sigma_{2}^{2}$

Kriteria Uji : Terima Ho jika Sig > 0,05

Dari tabel hasil output Lavene's Test diperoleh bahwa pada Based on Mean nilai Sig = 0,086 $>0.05$, sehingga Ho diterima, artinya varians kedua kelompok data adalah sama atau kedua data adalah homogen.

\subsection{Pengujian Hipotesis Statistik}

Untuk uji hipotesis penelitian digunakan uji T (Independent Samples T Test) melalui software SPSS 17. Adapun hipotesis statistiknya adalah sebagai berikut :

$\mathrm{H}_{0}: \mu_{1} \leq \mu_{2}$ (Rata-rata kemampuan membuktikan pada mahasiswa kelas eksperimen lebih rendah atau sama dengan rata-rata kemampuan membuktikan mahasiswa kelas kontrol)

$\mathrm{H}_{1}: \mu_{1}>\mu_{2}$ (Rata-rata kemampuan membuktikan pada mahasiswa kelas eksperimen lebih tinggi daripada rata-rata kemampuan membuktikan mahasiswa kelas kontrol)

Kriteria Uji : Tolak Ho jika p-value $=$ sig $/ 2<0,05$

Karena berdasarkan Levene's Test asumsi kedua variansi sama besar (equal variances assumed) terpenuhi atau varians data homogen yang terlihat dari nilai sig $=0,086>0,05$, maka dari tabel hasil output Independent Samples T Test diperoleh nilai $\mathrm{t}=3,214, \mathrm{db}=55$ dan $\mathrm{p}$-value $=0,002 / 2=0,001<$ 0,05 sehingga Ho ditolak. Dengan demikian hipotesis penelitian yang diajukan teruji oleh data, sehingga disimpulkan bahwa rata-rata kemampuan membuktikan pada mahasiswa kelas eksperimen lebih tinggi daripada rata-rata kemampuan membuktikan mahasiswa kelas kontrol. Dengan kata lain bahwa rata-rata kemampuan membuktikan konsep-konsep Aljabar Abstrak mahasiswa yang diberikan pemahaman teknik-teknik pembuktian matematika secara eksplisit di awal perkuliahan bersamaan 
dengan penerapan strategi Abduktif-Deduktif lebih tinggi dari pada mahasiswa yang memperoleh pembelajaran secara konvensional.

\subsection{Pembahasan Hasil Penelitian}

Dari hasil penelitian diatas diperoeleh bahwa kemampuan membuktikan konsep-konsep Aljabar Abstrak mahasiswa yang diberikan pemahaman teknik-teknik pembuktian matematika secara eksplisit di awal perkuliahan bersamaan dengan penerapan strategi Abduktif-Deduktif lebih tinggi dari pada mahasiswa yang memperoleh pembelajaran secara konvensional. Walaupun dari nilai rata-rata yang diperoleh perbedaannya tidak terlalu signifikan, yaitu skor rata-rata hasil posttest kemampuan membuktikan konsep Aljabar Abstrak pada kelas eksperimen adalah 58,77 dan untuk kelas kontrol adalah 50,59. Hal ini menunjukkan bahwa pembelajaran Aljabar Abstrak dengan menggunakan strategi Abduktif-Deduktif yang diawali dengan memberikan pembekalan secara eksplisit kepada mahasiswa akan metode pembuktian matematika memberikan kemampuan membuktikan yang lebih unggul daripada pembelajaran Aljabar Abstrak yang selama ini biasa dilakukan.

Hal ini sesuai dengan tujuan dikembangkannya metode pembuktian matematika, yaitu untuk meningkatkan kemampuan mahasiswa dalam memahami pembuktian, dan mengerjakan (membuktikan) pernyataan-pernyataan matematik. Materi Aljabar Abstrak yang sarat dengan buktibukti matematika untuk dapat memahami konsep-konsepnya menuntut mahasiswa untuk menguasai metode pembuktian matematika tersebut. Dengan memahami metode pembuktian matematika, mahasiswa bisa membaca, memahami, mengetahui prosedur, melakukan justifikasi, dan menuliskan kembali setiap proses pembuktian yang tersaji dalam konsep-konsepnya baik dalam bentuk aksioma, lemma, dalil ataupun teorema-teorema.

Strategi Abduktif-Deduktif yang diterapkan dalam pembelajaran Aljabar Abstrak dapat menjembatani proses mental mahasiswa dalam memahami konsep-konsepnya, dimana secara umum ada dua aksi yang langsung dapat dilakukan ketika berhadapan dengan masalah pembuktian. Pertama, menganalisis setiap informasi yang diberikan di dalam data, kemudian menyusunnya sehingga menghasilkan target-target antara, dan dari target-target ini disintesis lagi sehingga memperoleh target antara berikutnya, dan seterusnya. Target-target antara ini merupakan objek mental lain yang mungkin sudah dimiliki sebelumnya oleh mahasiswa. Proses memperoleh target antara dari data yang diberikan merupakan proses deduktif. Kedua adalah menganalisis target akhir yang diharapkan, dan merumuskan suatu target antara sehingga berdasarkan suatu aturan tertentu (definisi atau teorema) akan tiba pada target akhir itu. Proses mengkondisikan target antara dari target akhir merupakan proses abduktif. Sementara tahapan proses lainnya adalah melakukan aksi-aksi mental sehingga dapat menjembatani target antara hasil proses deduktif dengan target antara hasil proses abduktif yang diberi nama dengan proses kunci.

Tahap-tahapan proses mental yang diberikan dalam pembelajaran dengan strategi Abduktif-Deduktif diatas, dapat membantu, mengarahkan, mendampingi dan menuntun mahasiswa dalam memahami proses pembuktian konsep-konsep Aljabar Abstrak. Selain itu intervensi dosen dalam mendorong mahasiswa untuk melakukan aksi-aksi mental sehingga mereka dapat melakukan ketiga proses di atas adalah sangat menentukan. Ungkapan-ungkapan transaktif dan fasilitatif atau teknik scaffolding yang diterapkan dosen mengakibatkan diskusi transaktif yang terjadi mengarah pada pembentukan objekobjek mental baru terutama yang berkaitan dengan peningkatan kemampuan membuktikan konsepkonsep Aljabar Abstrak mahasiswa.

Sementara pada pembelajaran konvensional yang biasa diterapkan dalam perkuliahan Aljabar Abstrak dalam menunjukkan proses pembuktian konsep-konsepnya baik aksioma, lemma dan teorema, dimana dosen pada umumnya menggunakan logika deduktif yaitu menguraikan/menjabarkan dari premis/fakta yang diketahui secara deduktif sampai diperolehnya conclusion/kesimpulan atau dengan kata lain lebih dominan untuk menggunakan logika deduktif dalam menguraikan, menurunkan, ataupun menurunkan proses pembuktian konsep-konsep Aljabar Abstrak.

Maka dengan berimbangnya digunakan logika deduktif dan abduktif dalam proses mental mahasiswa pada pembelajaran dengan strategi PSAD, dimana logika tersebut dilatihkan terus menerus dalam setiap proses pembuktian konsep-konsep Aljabar Abstrak selama perkuliahan berlangsung, sehingga logis jika hasil penelitian yang diperoleh bahwa pembelajaran dengan strategi PSAD memberikan 
keunggulan daripada pembelajaran secara konvensional didalam meningkatkan kemampuan membuktikan konsep-konsep Aljabar Abstrak mahasiswa.

\section{Simpulan}

Berdasarkan hasil penelitian, didapatkan kesimpulan bahwa pada mahasiswa Jurusan Matematika FMIPA UNJ yang mengikuti perkuliahan Aljabar Abstrak, melalui pembekalan pemahaman teknik-teknik pembuktian matematika secara eksplisit di awal perkuliahan bersamaan dengan penerapan strategi Abduktif-Deduktif memiliki rata-rata kemampuan membuktikan konsepkonsep Aljabar Abstrak yang lebih tinggi dari pada yang memperoleh pembelajaran secara konvensional.

\section{Daftar Pustaka}

1. Arnawa, 2006. Meningkatkan Kemampuan Pembuktian Mahasiswa dalam Aljabar Abstrak Melalui Pembelajaran Berdasarkan Teori APOS. (Disertasi). Bandung: Universitas Pendidikan Indonesia.

2. Asikin, M. 2002. "Peningkatan Keefektifan Pembelajaran Pembuktian pada Struktur Aljabar melalui Model Belajar Perubahan Konseptual dengan CLS (Cooperative Learning Strategies)". Makalah pada Seminar Nasional Matematika di FMIPA UMN. Malang.

3. Carlson, D. 2003. "The Teaching and Learning of Tertiary Algebra". Makalah pada Seminar Nasional Aljabar dan Pengajaran Aljabar di Perguruan Tinggi. Jogjakarta.

4. Findel, B.R. 2001. Learning and Understanding in Abstract Algebra. (Disertasi). New Hampshire.

5. Hart, E. W. 1994. "A Conceptual Analysis of The Proof-Writing Performance of Expert and Novice Students in Elementary Group Theory”. Dalam J. J. Kaput \& Ed Dubinsky (ed.). Research Issues in Undergraduate Mathematics Learning. Washington: American Mathematical Society.

6. Kusnandi, 2008. Pembelajaran Matematika Dengan Strategi Abduktif-Deduktif Untuk Menumbuhkembangkan Kemampuan Membuktikan Pada Mahasiswa (Disertasi). Bandung: Universitas Pendidikan Indonesia

7. Leron, U.\& Dubinsky, E. 1995. "An Abstract Algebra Story". American Mathematical Monthly,

8. Moore, R C. 1994. Making the transition to Formal Proof, Educational Studies in Mathematics.

9. NCTM. 2000. Principles and Standars for School Mathematic. Reston, VA: NCTM

10. Sabri. 2003. Prospective Secondary School Teachers' Conceptions of Mathematical Proof in Indonesia (Tesis). Curtin University of Technology

11. -.-.- 2004. "Contextualizing Mathematical Proof with Constructivism". Makalah pada Conference on Recent Progress in Mathematics Education (CRPME 2004). ITB Bandung.

12. Uhlig, F. 2003. The Role of Proof in Comprehendingand Teaching ElementaryLinear Algebra. Educational Studies in Mathematics.

13. Yerison, 2011. Peningkatan Kemampuan Pembuktian dan Kemandirian Belajar Matematik Mahasiswa Melalui Pendekatan M-Apos (Disertasi). Bandung: Universitas Pendidikan Indonesia 